\title{
THE STRUCTURE OF THE OPTIMAL CONTROL IN THE PROBLEMS OF STRENGTH OPTIMIZATION OF STEEL GIRDERS
}

\section{Leszek Mikulski ${ }^{1}$}

\begin{abstract}
The paper concerns a strength optimization of continuous beams with variable cross-section. The continuous beams are subjected to a dead weight and a useful load, the six (seven) combinations of loads were analyzed. Optimal design problems in structural mechanics can by mathematically formulated as optimal control tasks. To solve the above formulated optimization problems, the minimum principle was applied. The paper is an introductory and survey paper of the treatment of realistically modelled optimal control problems from application in the structural mechanics. Especially those problems are considered, which include different types of constraints. The optimization problem is reduced to the solution of multipoint boundary value problems (MPBVP) composed of differential equations. Dimension of MPBVP is usually a large number, what produces numerical difficulties. Optimal control theory does not give much information about the control structure. The correctness of the assumed control structure can be checked after obtaining the solution of the boundary problem.
\end{abstract}

Keywords. Optimal control problems, necessary conditions, control variable inequality constraints, multipoint boundary-value problems, optimal switching structure.

\section{INTRODUCTION}

This article concerns theoretical, numerical and practical aspects of optimal control with state variable constraints. This class of optimal control problems has considerable and still increasing importance in engineering sciences, since it regards construction of models which better describe

\footnotetext{
${ }^{1}$ Prof. PhD Hab. Eng,. Chair of Structural and Material Mechanics, Faculty of Civil Engineering, Cracow University of Technology, ul.Warszawska 24, PL-31-155 Cracow, Poland, e-mail: mikul@pk.edu.pl
} 
reality. In precise modelling the issue of boundaries of domain of admissible values gains importance. This in turn results in setting of constraints on control and state variables which must be satisfied unconditionally. In the present paper a control matrix $U_{k}$ will be considered and we shall focus on the indirect method of multiple shooting, which has been proven to be efficient in many practical cases. In the indirect method the determination of the structure of control is crucial. It is this structure that describes the sequence of the occurrence of intervals and points with active (non-active) constraints. In case of the matrix control for an interval there are $n_{U}-1$ degrees of freedom, enabling optimization of control in this interval. Additionally, optimal control problems formulated in structural mechanics have certain characteristic properties: multiple control variables, numerous constraints on state variables, controls influencing state equations in a linear and nonlinear way, multi-phase problems requiring satisfying initial and boundary conditions as well as internal point conditions.

\section{Problem Statement}

In this study, the problem of the optimal choice of dimensions of cross-sections of steel multi-span I-beams is presented. The task was formulated within the control theory. Theoretical basis for the approach to the optimal shaping within the frames of the control theory may be found in [1],[7],[8]. The performed analysis was constrained to the following chosen instances: three-, four-and fivespan structural systems (b3, b4, b5) with defined load cases [3], [5], [6], [10], [11], [12]. Fig.1, Fig.2, Fig. 3 below show static diagrams of the assumed scenarios. From the mathematical point of view, the problem was reduced to solving a multi-point boundary value problem (MPBVP) for a system of 29 (25) ordinary differential state equations. 


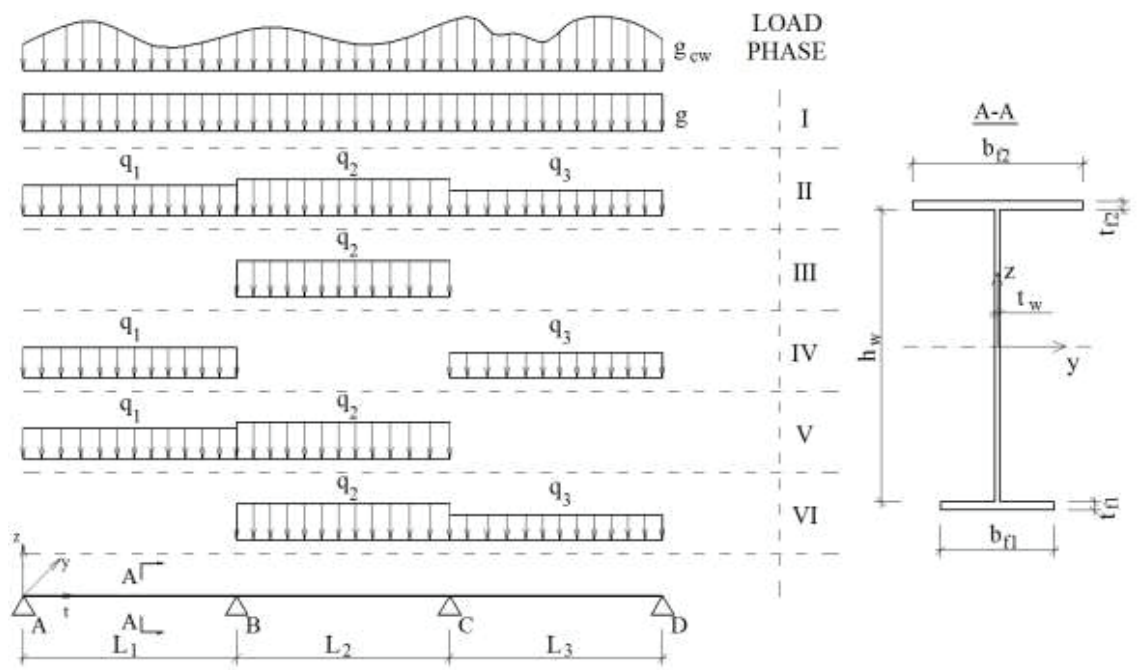

Fig.1. Static diagram and configuration of external forces for the three-span beam - b3. Source: own.

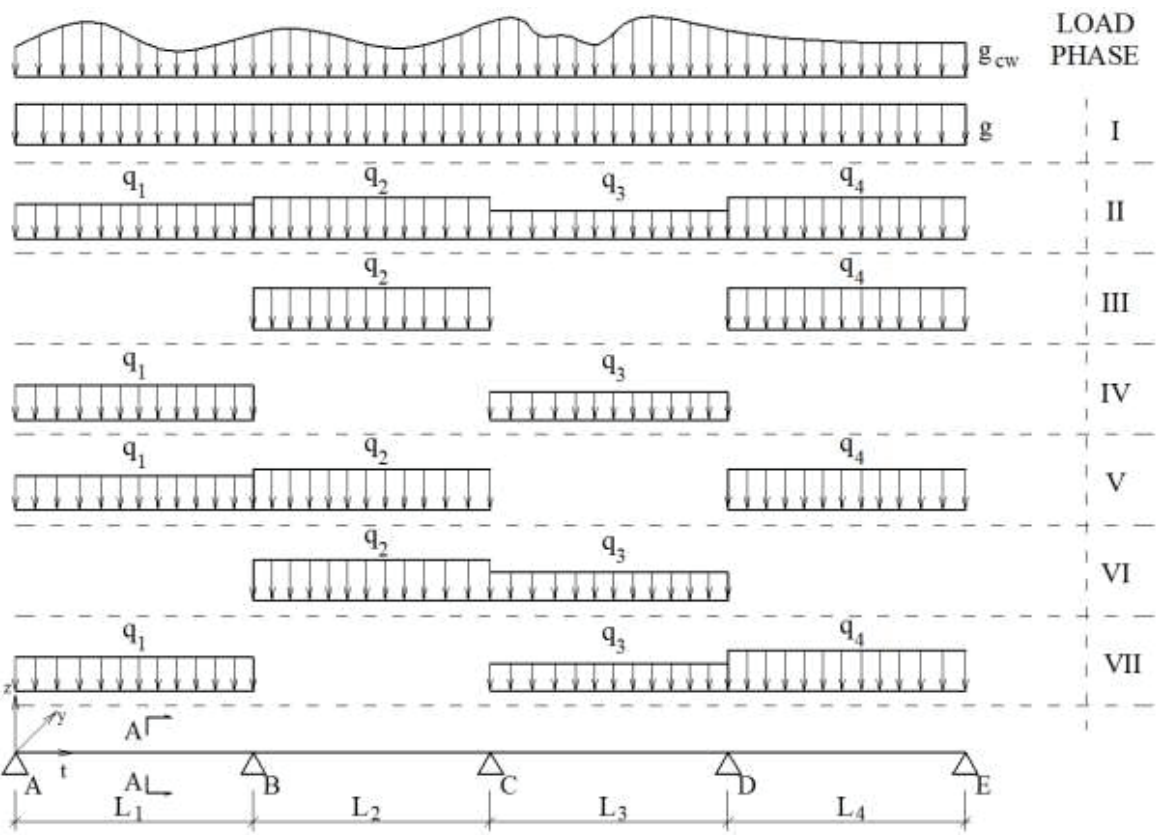

Fig.2. Static diagram and configuration of external forces for the four-span beam - b4. Source: own. 


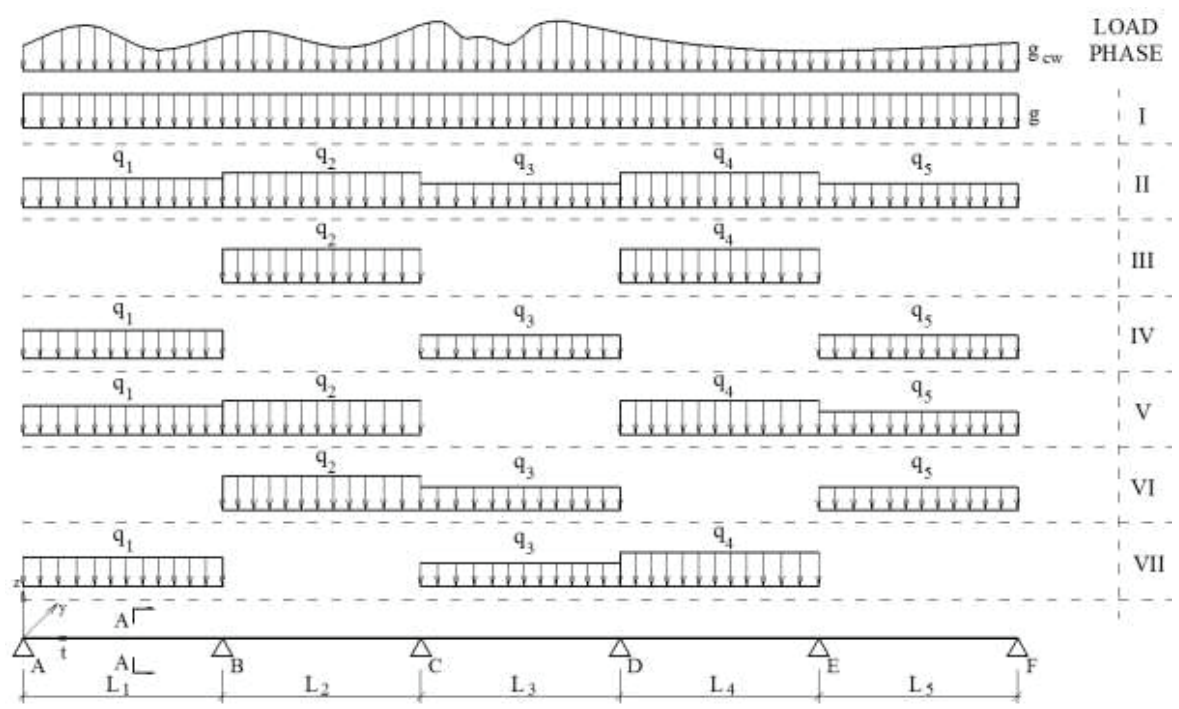

Fig.3. Static diagram and configuration of external forces for the five-span beam - b5. Source: own.

\subsection{DYNAMICAL SYSTEM}

The state equations which describe deformation of the three-span beam b3, subjected to six load cases (Fig.1), have following form:

$$
x_{i}^{\prime}=f_{i}\left(x_{i}, U_{k}, t\right), i=1, \ldots, 25, k=1,2,3, t \in[0, l]
$$

In the first characteristic interval (phase) $t \in(0,15.00)$ the state equations are written as follows:

$$
\begin{aligned}
& x_{1}^{\prime}=x_{2}, \quad x_{2}^{\prime}=\frac{x_{3}}{B_{1} \cdot J_{s}}, \quad x_{3}^{\prime}=x_{4}, \quad x_{4}^{\prime}=-g-A_{2} \cdot A_{s}, \\
& x_{5}^{\prime}=x_{6}, \quad x_{6}^{\prime}=\frac{x_{7}}{B_{1} \cdot J_{s}}, \quad x_{7}^{\prime}=x_{8}, \quad x_{8}^{\prime}=-q_{1}-A_{2} \cdot A_{s}, \\
& x_{9}^{\prime}=x_{10}, \quad x_{10}^{\prime}=\frac{x_{11}}{B_{1} \cdot J_{s}}, \quad x_{11}^{\prime}=x_{12}, \quad x_{12}^{\prime}=-A_{2} \cdot A_{s}, \\
& x_{13}^{\prime}=x_{14}, \quad x_{14}^{\prime}=\frac{x_{15}}{B_{1} \cdot J_{s}}, \quad x_{15}^{\prime}=x_{16}, \quad x_{16}^{\prime}=-q_{1}-A_{2} \cdot A_{s}, \\
& x_{17}^{\prime}=x_{18}, \quad x_{18}^{\prime}=\frac{x_{19}}{B_{1} \cdot J_{s}}, \quad x_{19}^{\prime}=x_{20}, \quad x_{20}^{\prime}=-q_{1}-A_{2} \cdot A_{s}, \\
& x_{21}^{\prime}=x_{22}, \quad x_{22}^{\prime}=\frac{x_{23}}{B_{1} \cdot J_{s}}, \quad x_{23}^{\prime}=x_{24}, \quad x_{24}^{\prime}=-q_{1}-A_{2} \cdot A_{s}, \quad x_{25}^{\prime}=A_{2} \cdot A_{s}, \\
& A_{s}=U_{1} \cdot t_{f 1}+U_{2} \cdot t_{f 2}+U_{3} \cdot t_{w}, \quad U_{1}=b_{f 1}, \quad U_{2}=b_{f 2}, \quad U_{3}=h_{w}, \\
& J_{s}=\frac{t_{w} U_{3}^{3}}{12}+\frac{t_{f 1}^{3} U_{1}}{12}+U_{1} t_{f 1}\left(\frac{U_{3}+t_{f 1}}{2}\right)^{2}+\frac{t_{f 2}^{3} U_{2}}{12}+U_{2} t_{f 2}\left(\frac{U_{3}+t_{f 2}}{2}\right)^{2},
\end{aligned}
$$


$x_{1} ; x_{5} ; x_{9} ; x_{13} ; x_{17} ; x_{21}$ - deflections, $x_{2} ; x_{6} ; x_{10} ; x_{14} ; x_{18} ; x_{22}$ - angles of rotation, $x_{3} ; x_{7} ; x_{11} ; x_{15} ; x_{19} ; x_{23}$ - bending moments about y-axis, $x_{4} ; x_{8} ; x_{12} ; x_{16} ; x_{20} ; x_{24}$-shearing forces onto z-axis

In the next characteristic intervals, the following differential equations are changed:

$$
\begin{aligned}
& t \in(15.00 \div 30.00) \\
& x_{4}^{\prime}=-g-A_{2} \cdot A_{s}, \quad x_{8}^{\prime}=-q_{2}-A_{2} \cdot A_{s}, \quad x_{12}^{\prime}=-q_{2}-A_{2} \cdot A_{s}, \\
& x_{16}^{\prime}=-A_{2} \cdot A_{s}, \quad x_{20}^{\prime}=-q_{2}-A_{2} \cdot A_{s}, \quad x_{24}^{\prime}=-q_{2}-A_{2} \cdot A_{s}, \\
& t \in(30.00 \div 39.00) \\
& x_{4}^{\prime}=-g-A_{2} \cdot A_{s}, \quad x_{8}^{\prime}=-q_{3}-A_{2} \cdot A_{s}, \quad x_{12}^{\prime}=-A_{2} \cdot A_{s}, \\
& x_{16}^{\prime}=-q_{3}-A_{2} \cdot A_{s}, \quad x_{20}^{\prime}=-A_{2} \cdot A_{s}, \quad x_{24}^{\prime}=-q_{3}-A_{2} \cdot A_{s},
\end{aligned}
$$

The state equations Eq.(2.2) and Eq.(2.3) are completed with initial and boundary conditions, depending on the way the girder is supported:

$$
\begin{gathered}
x_{1}(0)=0, \quad x_{3}(0)=0, \quad x_{9}(0)=0, \quad x_{13}(0)=0, \quad x_{17}(0)=0, \quad x_{21}(0)=0, \quad x_{25}(0)=0, \\
x_{3}(0)=0, \quad x_{7}(0)=0, \quad x_{11}(0)=0, \quad x_{15}(0)=0, \quad x_{19}(0)=0, \quad x_{23}(0)=0, \\
x_{1}(l)=0, \quad x_{5}(l)=0, \quad x_{9}(l)=0, \quad x_{13}(l)=0, \quad x_{17}(l)=0, \quad x_{21}(l)=0, \\
x_{3}(l)=0, \quad x_{7}(l)=0, \quad x_{11}(l)=0, \quad x_{15}(l)=0, \quad x_{19}(l)=0, \quad x_{23}(l)=0, \quad l=\Sigma L_{i},
\end{gathered}
$$

Furthermore, internal point conditions and discontinuity conditions must be satisfied at the middle support points:

$$
\begin{aligned}
& x_{1}\left(L_{i}\right)=0, \quad x_{5}\left(L_{i}\right)=0, \quad x_{9}\left(L_{i}\right)=0, \quad x_{13}\left(L_{i}\right)=0, \quad x_{17}\left(L_{i}\right)=0, \quad x_{21}\left(L_{i}\right)=0, \\
& x_{4}\left(L_{i}^{+}\right)=x_{4}\left(L_{i}^{-}\right)+C_{i 1}, \quad x_{8}\left(L_{i}^{+}\right)=x_{8}\left(L_{i}^{-}\right)+C_{i 2}, \\
& x_{12}\left(L_{i}^{+}\right)=x_{12}\left(L_{i}^{-}\right)+C_{i 3}, \quad x_{16}\left(L_{i}^{+}\right)=x_{16}\left(L_{i}^{-}\right)+C_{i 4}, \\
& x_{20}\left(L_{i}^{+}\right)=x_{20}\left(L_{i}^{-}\right)+C_{i 5}, \quad x_{24}\left(L_{i}^{+}\right)=x_{24}\left(L_{i}^{-}\right)+C_{i 6}, \quad C_{i j}^{\prime}=0, i=1,2 .
\end{aligned}
$$

\subsection{Physical CONSTRAints, ADMissible CONTROLS, COST FUnCTIONAL}

Normal stresses for each load case may be expressed as:

$$
\begin{gathered}
S_{1}=\frac{\left|x_{3}\right| \cdot z}{J_{s}}, \quad S_{2}=\frac{\left|x_{7}\right| \cdot z}{J_{s}}, \quad S_{3}=\frac{\left|x_{11}\right| \cdot z}{J_{s}}, \\
S_{4}=\frac{\left|x_{15}\right| \cdot z}{J_{s}}, \quad S_{5}=\frac{\left|x_{19}\right| \cdot z}{J_{s}}, \quad S_{6}=\frac{\left|x_{23}\right| \cdot z}{J_{s}}, \\
Y_{1}=\max \left(S_{1}, S_{2}, S_{3}, S_{4}, S_{5}, S_{6}\right) \\
Y_{2}=\max \left(\left|x_{1}\right|,\left|x_{5}\right|,\left|x_{9}\right|,\left|x_{13}\right|,\left|x_{17}\right|,\left|x_{21}\right|\right) .
\end{gathered}
$$


In the task of the optimal control, the following geometric constraints, constraints on stresses and displacements were assumed:

$$
\begin{aligned}
& U_{i} \in U_{d}, \quad U_{1} \in(0.15 \div 0.40), \quad U_{2} \in(0.15 \div 0.40), \quad U_{3} \in(0.3 \div 1.5), \\
& g_{1}=f_{d}-Y_{1} \geq 0, \quad g_{2}=Y_{d}-Y_{2} \geq 0
\end{aligned}
$$

The constraint $g_{1}=0$ is active along an interval and enables determination of the $U_{3}$ control in the interval in which it is active [2], [4]. The constraint $g_{2}=0$ is active in a point and it does not depend explicitly on controls [7], [8]. Hence, we consider the so-called 'mixed state-control constraints' of the following type:

$$
g_{i}[x(t), U(t)] \geq 0, g_{i}: R^{n+k} \Rightarrow R^{l}
$$

where $g_{i}$ explicitly depends on the control vector $\frac{\partial g_{i}}{\partial U_{k}} \neq 0$. The objective function is defined as the total volume of steel and may be expressed as follows:

$$
x_{25}=\int_{0}^{l} A_{s} d t, x_{25}^{\prime}=A_{s}, x_{25}(0)=0
$$

the optimization task requires minimization of the variable $x_{25}(l)$ with respect to the controls $U_{k}(t)$, while meeting the constraints $g_{i} \geq 0$ and satisfying the conditions given by Eq.(2.2)-(2.5):

$$
\min _{\mathrm{U}_{\mathrm{k}}}\left\{x_{25}\right\}
$$

\subsection{NECESSARY CONDITIONS}

Application of the minimum principle results in the following conditions for the optimal control [1], [6], [7],[8]:

$$
\begin{aligned}
& H=\sum_{1}^{25} \lambda_{i} \cdot f_{i}\left(x_{i}, U_{k}\right)+\mu_{1} \cdot g_{1}+\mu_{2} \cdot g_{2}, i=1, \ldots, 25, k=1,2,3 \\
& \frac{\partial H}{\partial U_{k}}=0, \\
& \mu_{1}(t)=\left\{\begin{array}{l}
=0 \text { if } g_{1}>0, \\
>0 \text { if } g_{1}=0, \frac{\partial g_{1}}{\partial x} \neq 0, \\
\geq 0 \text { if } g_{1}=0, \frac{\partial g_{1}}{\partial x}=0 .
\end{array}\right.
\end{aligned}
$$

If $\frac{\partial g_{1}}{\partial U_{k}} \neq 0$, the multiplier $\mu$ is given by means of Eq.(2.12): 


$$
\mu_{1}=-\left(\frac{\partial g_{1}}{\partial U_{k}}\right)^{-1}\left(\lambda^{T} \cdot \frac{\partial f_{i}}{\partial U_{k}}\right)
$$

The next degree of complexity is given by optimal control problems with the state variable inequality constraints: $g_{2}(x(t)) \geq 0$. Optimal control problems may have the so-called 'pure state inequality constraints'. The pure state constraints are in principle more difficult to deal with than the mixed control-state constraints, since $g_{2}$ does not explicitly depend on $U_{k}$ and x can be controlled only indirectly via propagation through the state equations. If the response $x$ just touches the boundary at $\theta_{c}$, i.e. $g_{2}\left(\theta_{c} ; x\left(\theta_{c}\right)\right)=0$, and $\mathrm{x}$ is in the interior just before and after $\theta_{c}$, then $\theta_{c}$ is called a contact point. These extra constraints give rise to jump conditions for adjoint variables and the Hamiltonian function [7], [8]:

$$
\begin{gathered}
\lambda\left(\theta_{1}^{-}\right)^{T}=\lambda\left(\theta_{1}^{+}\right)^{T}+\pi\left(\theta_{1}\right) \frac{\partial g}{\partial x}, \\
H\left(\theta_{1}^{-}\right)=H\left(\theta_{1}^{+}\right)-\pi\left(\theta_{1}\right) \frac{\partial g}{\partial t} .
\end{gathered}
$$

In case of multiple control variables $n_{U}>1$, the laws of control on constraints depend also on adjoint variables, which makes the boundary value problem highly non-linear. The adjoint variables $\lambda_{i}$ satisfy the equations:

$$
\lambda_{i}^{\prime}=-\frac{\partial H}{\partial x_{i}}, i=1, \ldots, 25 .
$$

The boundary conditions for adjoint variables result from transversality conditions. It may be noticed that for $x_{i}$, which are discontinuous in the middle points, the corresponding adjoint variables are equal to zero. If state variables are fixed in the middle points $L_{i}$, the respective adjoint variables are discontinuous [6]:

$$
\begin{aligned}
& x_{4}\left(L_{i}^{+}\right)=x_{4}\left(L_{i}^{-}\right)+C_{11} \Rightarrow \lambda_{4}\left(L_{i}\right)=0, \\
& x_{1}\left(L_{i}\right)=0 \Rightarrow \lambda_{1}\left(L_{i}^{+}\right)=\lambda_{1}\left(L_{i}^{-}\right)+D_{i 1}, \\
& x_{5}\left(L_{i}\right)=0 \Rightarrow \lambda_{5}\left(L_{i}^{+}\right)=\lambda_{5}\left(L_{i}^{-}\right)+D_{i 2}, \\
& x_{9}\left(L_{i}\right)=0 \Rightarrow \lambda_{9}\left(L_{i}^{+}\right)=\lambda_{9}\left(L_{i}^{-}\right)+D_{i 3}, \quad \text { (Fig. 5, 6), } \\
& x_{13}\left(L_{i}\right)=0 \Rightarrow \lambda_{13}\left(L_{i}^{+}\right)=\lambda_{13}\left(L_{i}^{-}\right)+D_{i 4}, \quad \text { (Fig. 7,8,11,12,15,16), } \\
& x_{17}\left(L_{i}\right)=0 \Rightarrow \lambda_{17}\left(L_{i}^{+}\right)=\lambda_{17}\left(L_{i}^{-}\right)+D_{i 5}, \\
& x_{21}\left(L_{i}\right)=0 \Rightarrow \quad \lambda_{21}\left(L_{i}^{+}\right)=\lambda_{21}\left(L_{i}^{-}\right)+D_{i 6}, \quad i=1,2 .
\end{aligned}
$$

If the solution meets the necessary condition for being the optimal one, the Hamilton function is piecewise constant (Fig.5 (b)), Fig.7 (b), Fig.8 (b)). 


\section{NUMERICAL SIMULATION}

The a priori assumption of a certain structure of the optimal control is not an important constraint, since it is anyway going to be verified by the optimality conditions during the solution. In case of the analysis of $\mathbf{b 3}$ the iterative procedure was convergent for the following structure of the optimal solution given by Eq.(3.1), Fig.4, Fig.5 (a). The value of the objective function was here $x_{25}(t=$ $39.00)=0.493724$.

$$
U_{3}(t)=\left\{\begin{array}{cll}
0.30 & t \in(0.00 \div 1.50), & \\
U_{o p t} & t \in(1.50 \div 12.75), & g_{2}=0, \mu_{2} \neq 0,(t=7.375)-(\text { Fig. } 7(b)), \\
0.30 & t \in(12.75 \div 14.00), & \\
U_{\sigma} & t \in(14.00 \div 15.00), & g_{1}=0, \mu_{1} \neq 0, \\
U_{o p t} & t \in(15.00 \div 27.00), & g_{2}=0, \mu_{2} \neq 0,(t=22.50)-(\text { Fig. 6(b)), } \\
0.30 & t \in(27.00 \div 28.75), & \\
U_{\sigma} & t \in(28.75 \div 30.00), & g_{1}=0, \mu_{1} \neq 0, \\
U_{o p t} & t \in(30.00 \div 37.95), & g_{2}=0, \mu_{2} \neq 0,(t=35.10)-(\text { Fig. 7(b)) }, \\
0.30 & t \in(37.95 \div 39.00), &
\end{array}\right.
$$

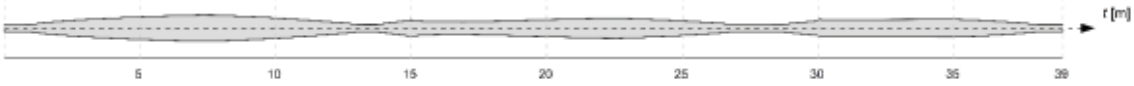

Fig.4. The optimal solution for b3, with structure given by Eq. (3.1), proportional dimensions. Source: own.

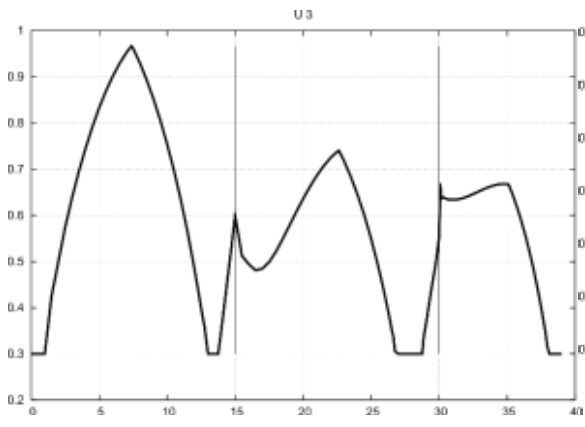

(a)

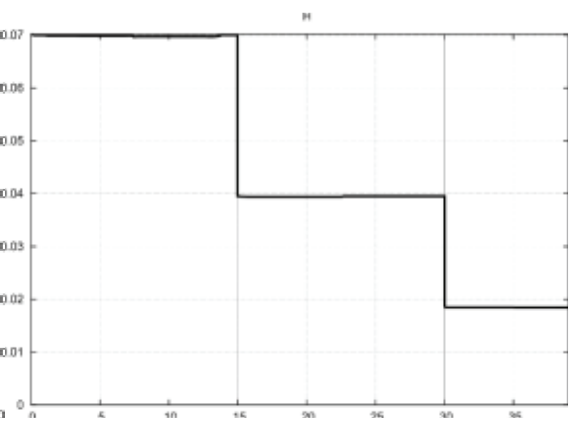

(b)

Fig.5. (a) The optimal solution given by Eq. (3.1) for b3, (b) Hamiltonian. Source: own. 


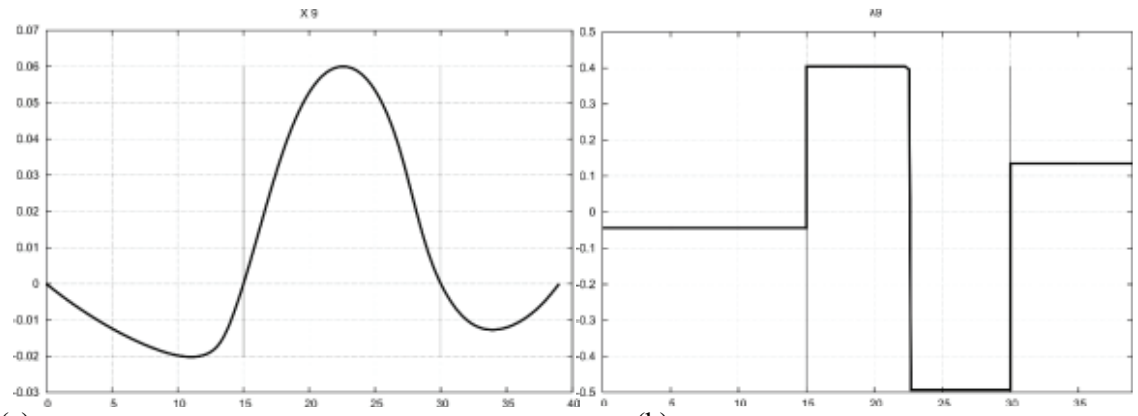

(a)

(b)

Fig.6. (a) State variable $x_{9}$, case b3, (b) Adjoint variable $\lambda_{9}$. Source: own.

(a)

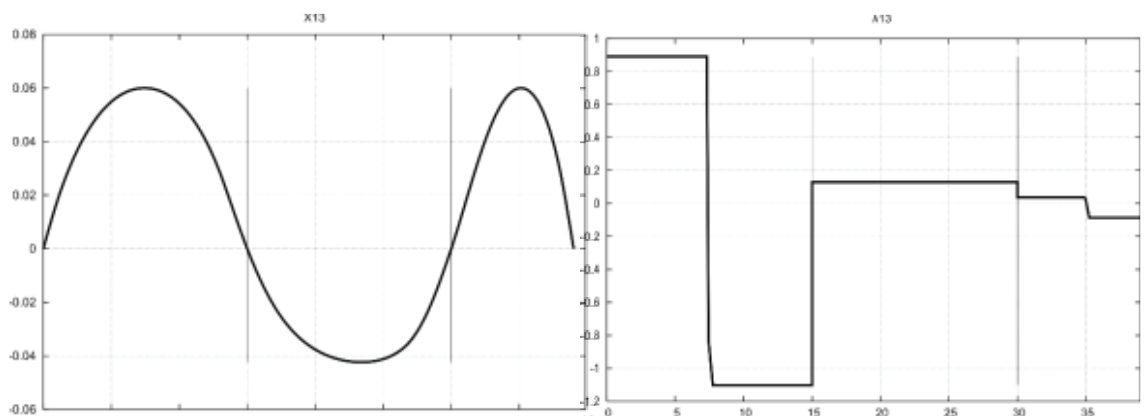

(b)

Fig.7. (a) State variable $x_{13}$, case b3, (b) Adjoint variable $\lambda_{13}$. Source: own.

For the three-span beam b3 with two control variables: $U_{1}=U_{2}, U_{3}$ and with the constraints: $U_{1}, U_{2} \in[0.15 \div 0.40], U_{3} \in[0.50 \div 1.00]$, the following structure of the optimal control was obtained:

$$
\begin{aligned}
& (0.50 t \in(0.00 \div 2.00) \\
& U_{\text {opt }} \quad t \in(2.00 \div 6.00), \quad g_{2}=0, \mu_{2} \neq 0,(t=7.375), \\
& 1.00 t \in(6.00 \div 8.50) \\
& U_{\text {opt }} \quad t \in(8.50 \div 12.50), \quad g_{1}=0, \mu_{1} \neq 0, \\
& 0.50 t \in(12.50 \div 14.00) \text {, } \\
& U_{1}=0.15, U_{3}(t)=\left\{\begin{array}{ccc}
0.50 & t \in(12.50 \div 14.00 \div 16.50), & U_{\sigma}=0, \mu_{1} \neq 0, \\
0.50 & t \in(16.50 \div 18.50), &
\end{array}\right. \\
& U_{\text {opt }} \quad t \in(18.50 \div 25.50), \quad g_{2}=0, \mu_{2} \neq 0,(t=22.50) \text {, } \\
& 0.50 \quad t \in(25.50 \div 29.50) \text {, } \\
& U_{\sigma} \quad t \in(29.50 \div 30.00) \quad g_{1}=0, \mu_{1} \neq 0 \text {, } \\
& U_{\text {opt }} \quad t \in(30.00 \div 37.50) \\
& 0.50 \quad t \in(37.50 \div 39.00)
\end{aligned}
$$


The optimal volume of the girder in this case was $x_{25}=0.443020$. In case when the three-span Ibeam had fixed web height $U_{3}=0.65$ and variable flange width $U_{1}=U_{2}$, the structure of control of the form given by Eq.(3.3) was obtained, assuming the volume of $x_{25}(t=39.00)=0.498929$.

$$
U_{1}(t)=\left\{\begin{array}{lll}
0.15 & t \in(0.00 \div 2.50), & \\
U_{o p t} & t \in(2.50 \div 7.00), \\
0.40 & t \in(7.00 \div 8.50), & \\
U_{o p t} & t \in(8.50 \div 11.50), & \\
0.15 & t \in(11.50 \div 14.50), & g_{2}=0, \mu_{2} \neq 0,(t=12.50) \\
U_{o p t} & t \in(14.50 \div 16.00), & g_{1}=0, \mu_{1} \neq 0, \\
0.15 & t \in(16.00 \div 29.50), & \\
U_{o p t} & t \in(29.50 \div 30.30), & g_{1}=0, \mu_{1} \neq 0, \\
0.15 & t \in(30.30 \div 33.00), & \\
U_{o p t} & t \in(33.00 \div 36.00) \\
0.15 & t \in(36.00 \div 39.00) & g_{2}=0, \mu_{2} \neq 0,(t=35,10)
\end{array}\right.
$$

For the four-span beam (b4) the optimal control structure had the following form (Fig.8 (a)):

$$
U_{3}(t)= \begin{cases}0.30 & t \in(0.00 \div 1.50), \\ U_{o p t} & t \in(1.50 \div 12.50), \quad g_{2}=0, \mu_{2} \neq 0,(t=7.375)-(\text { Fig.9(b) }) \\ 0.30 & t \in(12.50 \div 14.50), \\ U_{\sigma} & t \in(14.50 \div 15.80), \quad g_{1}=0, \mu_{1} \neq 0, \\ 0.30 & t \in(15.80 \div 20.60), \\ U_{o p t} & t \in(20.60 \div 27.45), \quad g_{1}=0, \mu_{1} \neq 0,(t=26.20), \\ 0.30 & t \in(27.45 \div 28.35), \\ U_{o p t} & t \in(28.35 \div 31.80), \\ 1.50 & t \in(31.80 \div 38.40), \quad g_{2}=0, \mu_{2} \neq 0,(t=35.40)-(\text { Fig.9(b) }), \\ U_{o p t} & t \in(38.40 \div 41.40) \\ 0.30 & t \in(41.40 \div 42.15) \\ U_{o p t} & t \in(42.15 \div 45.00) \\ 1.50 & t \in(45.00 \div 48.60) \\ U_{\text {opt }} & t \in(48.60 \div 53.40) \\ 0.30 & t \in(53.40 \div 54.00)\end{cases}
$$




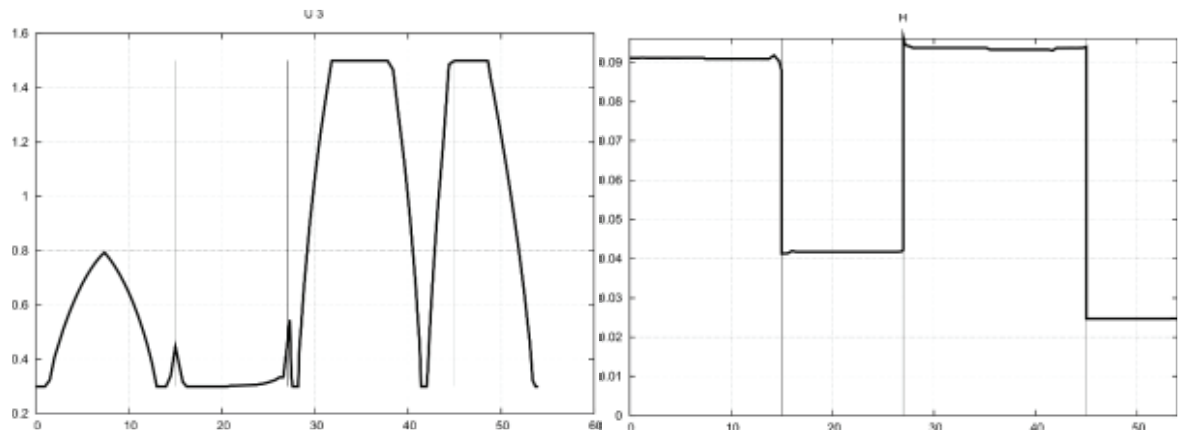

(a)

(b)

Fig.8. (a) The optimal control for $\mathbf{b} 4$ with structure given by Eq. (3.4) $L_{1}=15.0, L_{2}=12.0, L_{3}=18.0, L_{4}=9.0$. (b) Hamiltonian. Source: own.

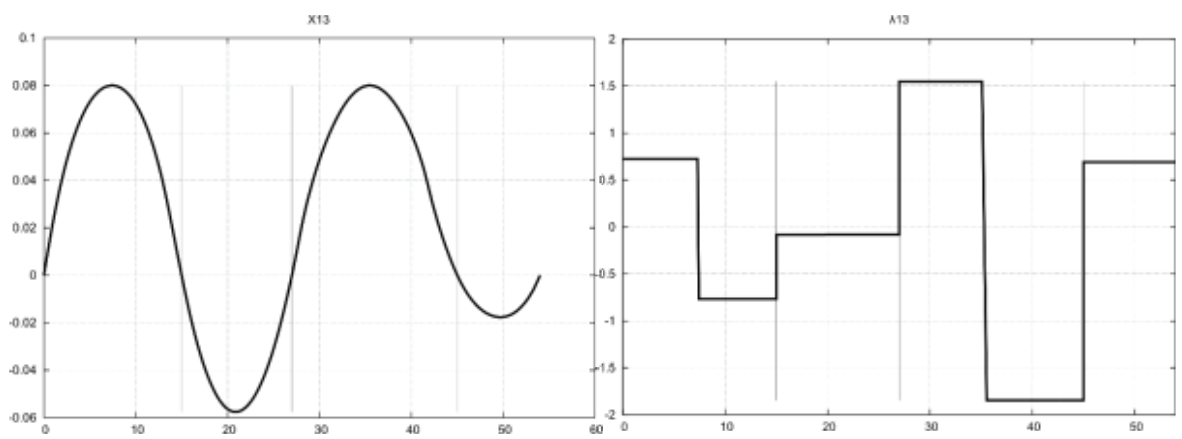

(a)

(b)

Fig.9. (a) State variable $x_{13}$, case b4, (b) Adjoint variable $\lambda_{13}$. Source: own.

If in the optimization of the four-span girder two control variables are introduced - the flange width and the web height $U_{1}, U_{3}$ - the structure of the solution was as follows: 


$$
\begin{cases}U_{1}=0.15, \quad U_{3}=0.50, \quad t \in(0.00 \div 2.00) \\ U_{1}=0.15, \quad U_{3}=U_{\text {opt }}, \quad t \in(2.00 \div 11.50), \quad g_{1}=0, \mu_{1} \neq 0 \\ U_{1}=0.15, \quad U_{3}=0.50, \quad t \in(11.50 \div 14.00), \\ U_{1}=0.15, \quad U_{3}=U_{\text {opt }}, \quad t \in(14.00 \div 15.80), \quad g_{1}=0, \mu_{1} \neq 0 \\ U_{1}=0.15, \quad U_{3}=U_{\text {opt }}, \quad t \in(15.80 \div 27.00), \\ U_{1}=U_{\text {opt }}, \quad U_{3}=1.00, \quad t \in(27.00 \div 27.60) \\ U_{1}=0.15, \quad U_{3}=U_{\text {opt }}, \quad t \in(27.60 \div 28.80) \\ U_{1}=0.15, \quad U_{3}=0.50, \quad t \in(28.80 \div 29.40) \\ U_{1}=0.15, \quad U_{3}=1.00, \quad t \in(29.40 \div 30.00) \\ U_{1}=U_{\text {opt }}, \quad U_{3}=1.00, \quad t \in(30.00 \div 33.60) \\ U_{1}=0.40, \quad U_{3}=1.00, \quad t \in(33.60 \div 37.20) \\ U_{1}=U_{\text {opt }}, \quad U_{3}=1.00, \quad t \in(37.20 \div 40.20) \\ U_{1}=0.15, \quad U_{3}=1.00, \quad t \in(40.20 \div 40.80) \\ U_{1}=0.15, \quad U_{3}=0.50, \quad t \in(40.80 \div 42.00) \\ U_{1}=U_{\text {opt }}, \quad U_{3}=1.00, \quad t \in(42.00 \div 45.00) \\ U_{1}=0.40, \quad U_{3}=1.00, \quad t \in(45.00 \div 47.40) \\ U_{1}=U_{\text {opt }}, \quad U_{3}=1.00, \quad t \in(47.40 \div 52.50) \\ U_{1}=0.15, \quad U_{3}=U_{\text {opt }}, \quad t \in(52.00 \div 53.40) \\ U_{1}=0.15, \quad U_{3}=0.50, \quad t \in(53.40 \div 54.00)\end{cases}
$$

It is worth noting that in the structure given by Eq.(3.5) presented above, for which the optimization task was convergent, the following regularity may be observed: if the control $U_{1}=U_{\text {opt }}$, then the control $U_{3}=1.00$ (maximum value constraint), while in case $U_{3}=U_{\text {opt }}$, then $U_{1}=0.15$ (minimum value constraint). For the control structure determined as above, the optimal volume was $x_{29}(t=54.00)=0.808831$. The optimization of the five-span beam (b5) lead to the following structure (Fig.9 (a)):

$$
U_{3}(t)=\left\{\begin{array}{lll}
0.30 & t \in(0.00 \div 2.40), & \\
U_{\text {opt }} & t \in(2.40 \div 7.80), & g_{2}=0, \mu_{2} \neq 0,(t=5.55)-(\text { Fig.11(b) }) \\
0.30 & t \in(7.80 \div 12.00), & g_{1}=0, \mu_{1} \neq 0,(t=12.00) \\
U_{\text {opt }} & t \in(12.00 \div 20.55), & g_{1}=0, \mu_{1} \neq 0, \\
1.50 & t \in(20.55 \div 22.80), & \\
U_{\text {opt }} t \in(22.80 \div 26.40), & \\
1.50 & t \in(26.40 \div 34.50), & g_{2}=0, \mu_{2} \neq 0,(t=30.675)-(\text { Fig.11(b) }) \\
U_{\text {opt }} t \in(34.50 \div 50.25), & g_{1}=0, \mu_{1} \neq 0,(t \in(37.50 \div 38.10)) \\
030 & t \in(50.25 \div 54.00), & g_{1}=0, \mu_{1} \neq 0,(t=54.00) \\
U_{\text {opt }} & t \in(54.00 \div 61.65) & \\
0.30 & t \in(61.65 \div 63.00) &
\end{array}\right.
$$


(a)

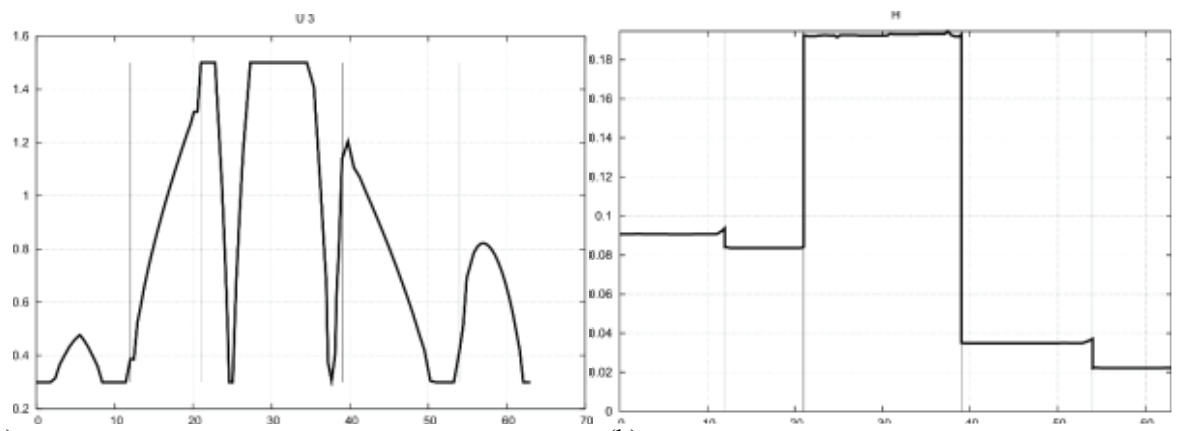

(b)

Fig.10. (a) The optimal control for $\mathbf{b 5}$ with structure given by Eq.(3.6)

$L_{1}=12.0, L_{2}=9.0, L_{3}=18.0, L_{4}=15.0, L_{5}=9.0$. (b) Hamiltonian. Source: own.

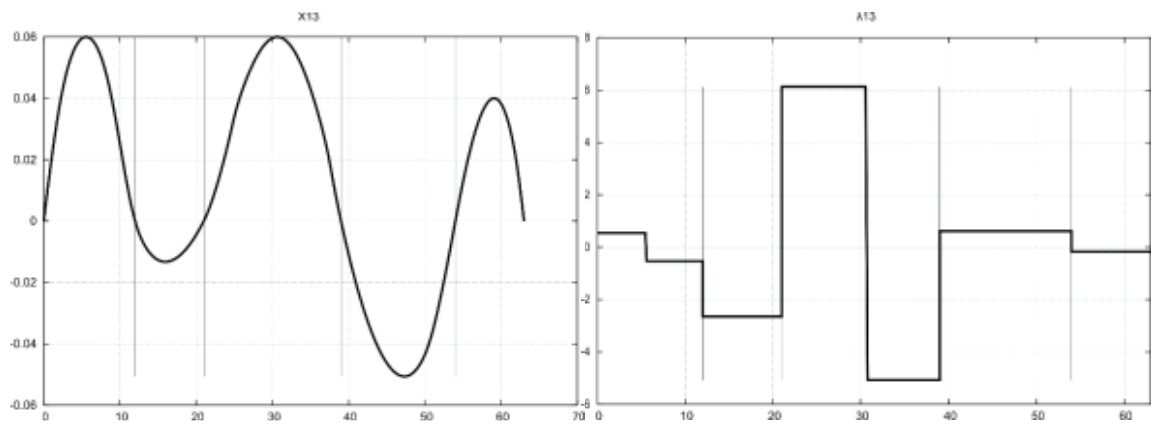

(a)

(b)

Fig.11. (a) State variable $x_{13}$, case b5, (b) Adjoint variable $\lambda_{13}$. Source: own.

For two control variables $U_{1}, U_{3}$ the following structure of the optimal solution proved to be appropriate: 


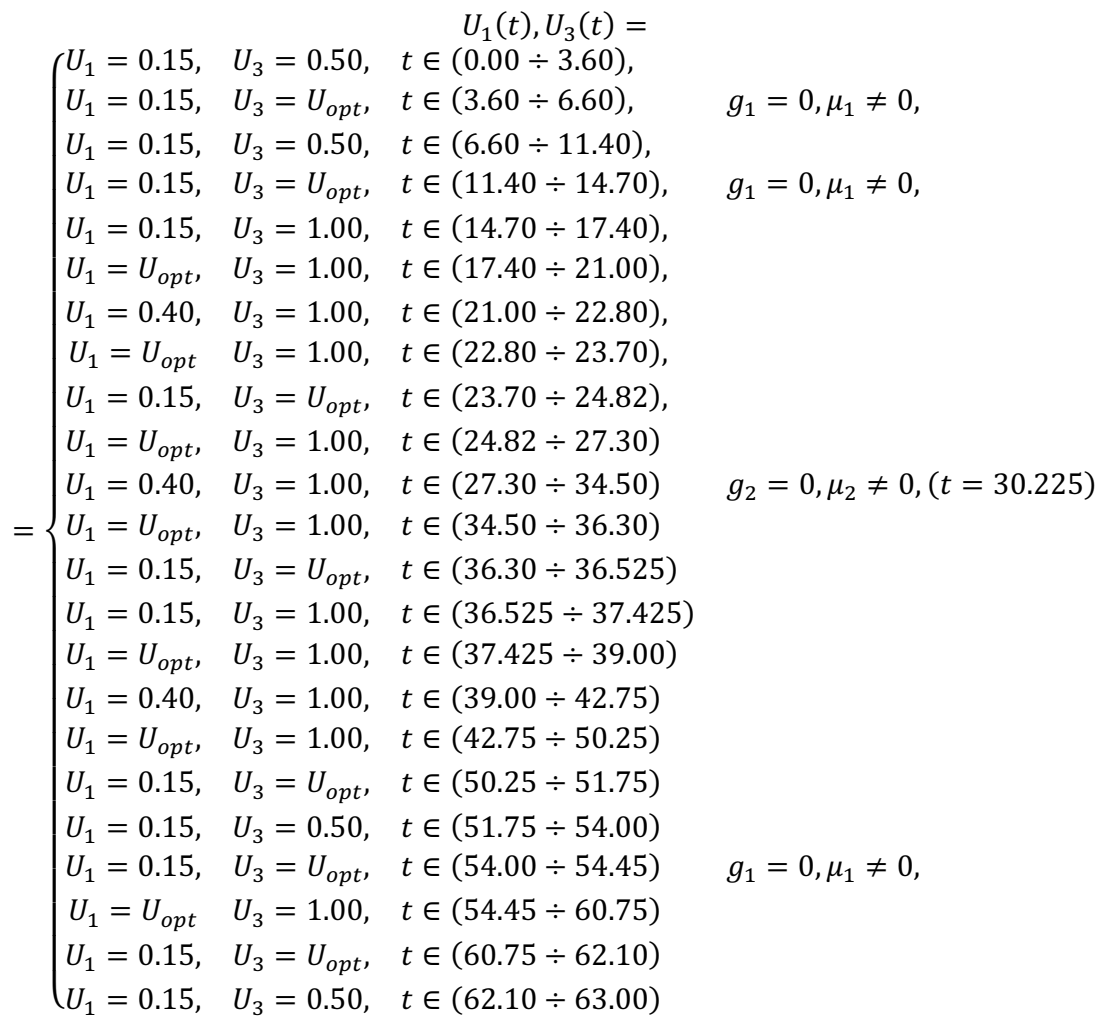

The multi-point boundary value problem (MPBVP) in the considered optimization task for the three-span girder (b3) is of dimension 94. The dimension consists of: 50 differential equations for state variables $x_{i}, i=1, \ldots, 25$ and adjoint variables $\lambda_{i}, i=1, \ldots, 25$, together with boundary conditions given by Eq.(2.4), internal point conditions given by Eq.(2.5) and Eq.(2.15), 12 unknown discontinuities of state variables in middle points $C_{i j}, 17$ discontinuities of adjoint variables in those points $D_{i j}, 8$ points of control switch $t_{i}, 5$ functions $\mu_{1}$ corresponding to constraints $g_{1}=0,3$ constants corresponding to pointwise constraints $g_{2}=0$ and, finally, 2 constants connected with discontinuity of the Hamilton function. The MPBVPs of the control structure given by Eq.(3.1)Eq.(3.7) was solved with the use of software Dircol-2.1 [9]. The software explicitly reaches for the necessary conditions of optimization, which requires: formulation of a adjoint system of differential equations (which cannot be specified automatically), very good initial estimates of values of state variables and adjoint variables and, last but not least, the knowledge of the structure of control in multi-phase problems. Only such an approach provides that the necessary conditions are satisfied with high precision. The fundamental benefit of application of the indirect method is the high 
precision, which cannot be achieved in the direct method. The obtained results are presented in figures showing active constraints. The obtained solutions satisfy the necessary conditions of optimality. Benefits due to the optimization, measured with the value of the objective function $x_{25}$ are equal to $37 \%$ (Tab.2). This article presents also results of the optimization of four- and five-span beams (b4, b5) with seven load combinations, for which the number of state equations was equal to 29. In the table below (Tab.1), the dimensions of the MPBVPs for all beams (b3, b4, b5) are listed.

Table 1. MPBVP for multi-span beams b3, b4, b5. Source: own.

\begin{tabular}{|c|c|c|c|c|c|c|c|c|c|}
\hline beam & $x_{i}$ & $\lambda_{i}$ & $C_{i j}$ & $D_{i j}$ & not cg H & Points $t_{i}$ & $\mu_{i}$ & MPBVP & Cost fun. \\
\hline b3- $U_{3}$ & 25 & 25 & 12 & 17 & 2 & 8 & 5 & 94 & 0.493724 \\
\hline b3- $U_{1}$ & 25 & 25 & 12 & 15 & 2 & 9 & 4 & 92 & 0.498929 \\
\hline b3- $U_{1}, U_{3}$ & 25 & 25 & 12 & 15 & 2 & 10 & 4 & 93 & 0.443020 \\
\hline b4- $U_{3}$ & 29 & 29 & 21 & 28 & 3 & 14 & 4 & 128 & 0.879924 \\
\hline $\mathbf{b 4}-U_{1}, U_{3}$ & 29 & 29 & 21 & 22 & 3 & 18 & 4 & 126 & 0.808832 \\
\hline $\mathbf{b 5}-U_{3}$ & 29 & 29 & 28 & 34 & 4 & 10 & 5 & 139 & 1.034974 \\
\hline b6- $U_{1}, U_{3}$ & 29 & 29 & 28 & 29 & 4 & 22 & 4 & 145 & 1.019096 \\
\hline
\end{tabular}

Table 2. Comparison of results of optimization, case b3. Source: own.

\begin{tabular}{|c|c|c|c|}
\hline & Girder volume $\left[\mathrm{m}^{3}\right]$ & $g_{1}=0$ & $g_{2}=$ \\
\hline$U_{3 o p t}$ & 0.493724 & Active in an interval & Active in a point \\
\hline$V\left(U_{3}=1.50\right)$ & 0.780000 & Not active & Not active \\
\hline$V\left(U_{3}=0.75\right)$ & 0.546329 & Active in an interval & Not active \\
\hline
\end{tabular}

\section{CONCLUSIONS}

In this paper three-, four- and five-span steel I-beams were optimized. The optimization regarded dimensions of the cross-section: the widths of the bottom and top flanges as well as the height of the web. The optimization was performed accounting for constraints due to ultimate limit state as well as serviceability limit state. The optimization task was formulated within the control theory, which was used in order to determine the necessary conditions of optimality in case when three control variables were assumed. The obtained MPBVP was solved with the use of the indirect method of multiple shooting. Special attention was paid to the structure of the optimal solution for a single or multiple controls. Chosen obtained state variables, conjugate variables, control variables and Hamilton functions are presented in the graphs and confirm that the necessary conditions of optimality were satisfied. 


\section{REFERENCES}

1. M. Gerdts, Optimal Control of Ordinary Differential Equations and Differential- Algebraic Equations, Habilitation Thesis, Department of Mathematics Un. Of Bayreuth, 2007

2. D. Jasińska, L. Mikulski, Optimal Shaping of the Composite Bridge by Means of Optimal Control, AIP Conference Proceedings, 2078 (2019), https://doi.org/10.1063/1.5092043

3. D. Jasińska, D. Kropiowska, The Optimal Design of an Arch Girder of Variable and Stiffness by Means of Control Theory, Hindawi, Mathematical Problems in Engineering, https://doi.org/10.1155/2018/8239464

4. D. Kropiowska, L. Mikulski, P. Szeptyński, Optimal Design of a Kirchhoff Plate of Variables Thickness by Application of the Minimum Principle, Structural and Multidisciplinary Optimization, https://doi.org/10.07/s00158-018-2148-3

5. L. Mikulski, H. Laskowski, Control Theory in Composite Structure Optimizing, Pomiary, Automatyka, Kontrola, 6 (2009), pp. 346 - 351

6. L. Mikulski, Control Structure in Optimization Problems of Bar Systems, Int.J.Appl.Math.Comput.Sci, 14, 4 (2014), pp. 515-529

7. Pesch H.J.: A practical guide to the solution of real-life optimal control problems, Contr.Cybern., 23, No.1-2 (1994), pp. 7-60

8. Pesch H.J.: O_-Line and On-Line Computation of Optimal Trajectories in the Aerospace Field. In: A.Miele, A.Salvetti (Eds.):Applied Mathematics in Aerospace Science and Engineering. Plenum Press, New York (1994) pp. 165-220.

9. von Stryk O.: Users Guide. A Direct Collocation Method for the Numerical Solution of Optimal Control Problems, TU Darmstadt, Fachgebiet Simulation und Systemoptiemirung,Version 2.1, April 2002

10. EN 1993-1-1- Design of steel structures. General structural rules

11. EN 1993-1-5- Design of steel structures. Plated structural elements

12. EN 1991-1-1 Actions on structures. General actions-Densities, self-weight, imposed loads for buildings.

\section{LIST OF FIGURES AND TABLES:}

Fig.1. Static diagram and configuration of external forces for the three-span beam - b3.

Rys.1. Schemat statyczny oraz rozkład obciążeń zewnętrznych dla belki trójprzęsłowej - b3.

Fig.2. Static diagram and configuration of external forces for the four-span beam - b4.

Rys.2. Schemat statyczny oraz rozkład obciążeń zewnętrznych dla belki czteroprzęsłowej - b4 .

Fig.3. Static diagram and configuration of external forces for the five-span beam - $\mathbf{b 5}$.

Rys.3. Schemat statyczny oraz rozkład obciążeń zewnętrznych dla belki pięcioprzęsłowej - b5.

Fig.4. The optimal solution for b3, with structure given by Eq.(3.1), proportional dimensions.

Rys.4. Optymalne rozwiązanie dla b3, ze strukturą daną przez Eq.(3.1), wymiary proporcjonalne.

Fig.5. (a)The optimal solution given by Eq.(3.1) for b3, (b) Hamiltonian.

Rys.5. (a) Optymalne rozwiązanie dane przez Eq.(3.1) dla b3, (b) Hamiltonian.

Fig.6. (a) State variable $x_{9}$, case b3, (b) Adjoint variable $\lambda_{9}$.

Rys.6. (a) Zmienna stanu $x_{9}$, przypadek b3, (b) Zmienna sprzężona $\lambda_{9}$.

Fig.7. (a) State variable $x_{13}$, case b3, (b) Adjoint variable $\lambda_{13}$.

Rys.7. (a) Zmienna stanu $x_{13}$, przypadek b3, (b) Zmienna sprzężona $\lambda_{13}$.

Fig.8. (a)The optimal control for b4 with structure given by Eq.(3.4). $L_{1}=15.0, L_{2}=12.0, L_{3}=18.0, L_{4}=$ 9.0, Hamiltonian. 
Rys.8. (a) Optymalne rozwiązanie dla b4 ze strukturą daną przez Eq.(3.4). $L_{1}=15.0, L_{2}=12.0, L_{3}=$ 18.0, $L_{4}=9.0$, Hamiltonian.

Fig.9. (a) State variable $x_{13}$, case b4, (b) Adjoint variable $\lambda_{13}$.

Rys.9. (a) Zmienna stanu $x_{13}$, przypadek b4, (b) Zmienna sprzężona $\lambda_{13}$.

Fig.10. (a)The optimal control for $\mathbf{b 5}$ with structure given by Eq.(3.6). $L_{1}=12.0, L_{2}=9.0, L_{3}=18.0, L_{4}=$ 15.0, $L_{5}=9.0$, Hamiltonian.

Rys.10. (a) Optymalne rozwiązanie dla b5 ze strukturą daną przez Eq.(3.6). $L_{1}=12.0, L_{2}=9.0, L_{3}=$ 18.0, $L_{4}=15.0, L_{5}=9.0$, Hamiltonian.

Fig.11. (a) State variable $x_{13}$, case b5, (b) Adjoint variable $\lambda_{13}$.

Rys.11. (a) Zmienna stanu $x_{13}$, przypadek b5, (b) Zmienna sprzężona $\lambda_{13}$.

Table 1. MPBVP for multi-span beams b3, b4, b5.

Tabela 1. Wielopunktowy problem brzegowy dla belek wieloprzęsłowych b3, b4, b5.

Table 2. Comparison of results of optimization, case b3.

Tabela 2. Porównanie wyników optymalizacji, przypadek b3.

\section{STRUKTURA OPTYMALNEGO STEROWANIA W PROBLEMACH OPTYMALIZACJI WYTRZYMALOŚCIOWEJ DŹWIGARÓW STALOWYCH.}

Slowa kluczowe: zagadnienia optymalnego sterowania, warunki konieczne, ograniczenia nierównościowe na zmienną decyzyjną, wielopunktowe zagadnienie brzegowe, struktura sterowania.

\section{STRESZCZENIE:}

Praca dotyczy optymalizacji wytrzymałościowej dźwigarów ciągłych trój-, cztero- i pięcioprzęsłowych o zmiennym dwuteowym przekroju poprzecznym. Dźwigary obciążone są ciężarem własnym i kombinacją obciążeń użytkowych (sześć lub siedem kombinacji). Deformacja dźwigara opisana jest przez układ równań różniczkowych z warunkami początkowymi i brzegowymi, ponadto do spełnienia pozostają wewnętrzne warunki brzegowe i warunki nieciągłości w pośrednich punktach podparcia. Rozważane są ograniczenia geometryczne, ograniczenia naprężeń i przemieszczeń. Jako funkcję celu wybrano objętość stali. Problemy optymalnego kształtowania formułowane są jako zadania teorii sterowania. Do rozwiązania zadań zaproponowano zasadę minimum. Problem optymalizacji redukuje się do rozwiązania wielopunktowego problemu brzegowego (WPPB) dla układu równań różniczkowych. Wymiar WPPB jest zwykle duży, co wymaga pokonania trudności numerycznych. Teoria sterowania nie dostarcza bowiem informacji o strukturze optymalnego rozwiązania dla której problem jest zbieżny. W pracy struktura sterowania opisuje kolejność występowania przedziałów i punktów z aktywnymi ograniczeniami. Poprawne przyjęcie tej struktury w rozwiązanych problemach jest zasadniczym osiągnięciem pracy. Uzyskane i prezentowane na wykresach wybrane zmienne stanu, zmienne sprzężone, zmienne decyzyjne, funkcje Hamiltona potwierdzają spełnienie warunków koniecznych optymalizacji. 